\title{
MAGNETIC SUSCEPTIBILITY CHANGES CORRELATED WITH PALEOENVIRONMENTAL AND LITHOLOGICAL CHANGES, WITHIN BOREHOLE CORES ON EITHER SIDES OF THE KALAMAKI-ISTHMIA FAULT IN CORINTH CANAL
}

\author{
Pallikarakis A. ${ }^{1}$, Papanikolaou I. ${ }^{1}$, Triantaphyllou M. ${ }^{2}$, Grützner C. ${ }^{3,4}$, \\ Migiros G. ${ }^{1}$, Reicherter K. ${ }^{3}$, Mason $\mathrm{J}^{3}{ }^{3}$ and Schneiderwind $\mathrm{S}^{3}$
}

${ }^{1}$ Laboratory Mineralogy - Geology, Department of Natural Resources Management \& Agricultural Engineering, Agricultural University of Athens, Iera Odos 75, Athina 118 55, Greece

${ }^{2}$ Hist. Geology-Paleontology Department, Faculty of Geology and Geoenvironment, National and Kapodistrian University of Athens, Panepistimiopolis 15784, Athens, Greece

${ }^{3}$ Institute of Neotectonics and Natural Hazards, RWTH Aachen University, Lochnerstr. 4-20, 52064 Aachen, Germany

${ }^{4}$ now at: COMET, Bullard Laboratories, Department of Earth Sciences, University of Cambridge, Madingley Rise, Madingley Road, CB3 OEZ Cambridge, United Kingdom.

\begin{abstract}
The most important active fault that intersects the eastern tip of Corinth Canal,the Kalamaki-Isthmia fault, is studied in detail, involving data analysis from nine boreholes, magnetic susceptibility measurements within boreholes and paleoenvironmental interpretations. Samples taken from boreholes were analysed and paleoenvironmental changes in the sequence are described. We correlate magnetic susceptibility (MS) measurements with paleoenvironmental and lithological alternations within the boreholes. We have ascribed low MS values to marine highstand deposits and high MS values to lowstand terrestrial deposits. Glacioeustatic sea level changes and tectonic movements have led to a very complicated lithosedimentary pattern that involves subaerial exposure, fluvialterrestrial, lagoonal, shallow marine environments and possibly even some lake sediments. Our results indicate that the Kalamaki fault is active and has a low slip rate of $0.05 \pm 0.02 \mathrm{~mm} / \mathrm{yr}$.
\end{abstract}

Keywords: Benthic foraminifera, active faulting, Corinth gulf, Saronic Gulf.

\section{Пєрі́ $\eta \psi \eta$}

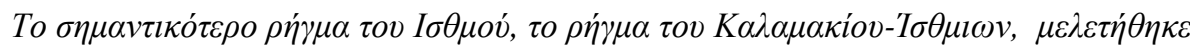

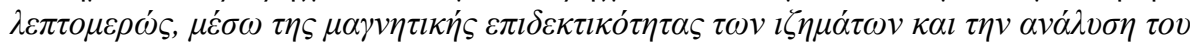

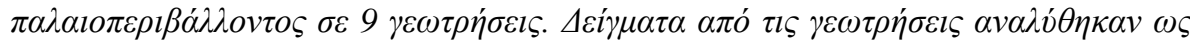

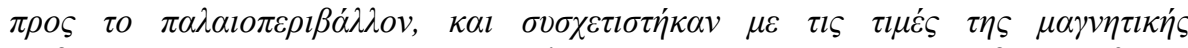

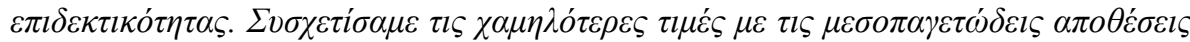

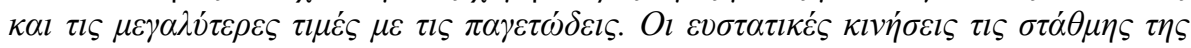

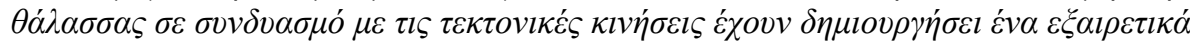

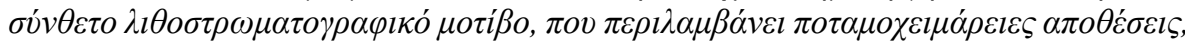

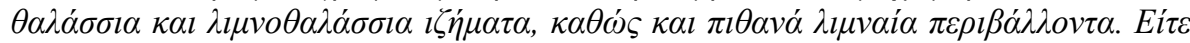




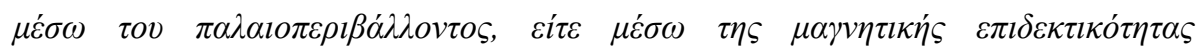

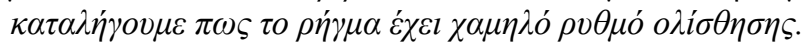

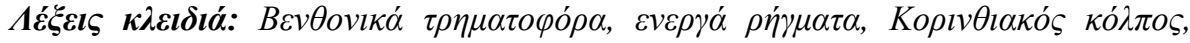
$\Sigma \alpha \rho \omega \nu \iota \kappa o ́ \varsigma \kappa o ́ \lambda \pi o \varsigma$.

\section{Introduction}

The Corinth region is influenced by significant active normal faults, such as the Kechriaie, the South Alkyonides Fault System (SAFS) and the Loutraki faults (e.g. Armijo et al., 1996; Collier et al., 1992; Roberts et al., 2009). Shorter normal faults located at the Canal have also affected the topography displacing Plio-Pleistocene sediments (Figure 1). Currently, the entire Isthmus undergoes uplift controlled by the major faults north of the Perachora peninsula. Glacioeustatic sea level changes and/or tectonic movements have led to a complicated lithosedimentary pattern with alternating marls, sands and gravels of Plio-Pleistocene age (e.g. Freyberg, 1973; Collier, 1990; Collier and Thomson, 1991; Collier and Dart, 1991). The Corinth Canal offers a unique opportunity to study the faults in the area. Most of these faults do not displace the topography and are of limited length. They are commonly considered secondary structures with low slip-rates (Papanikolaou et al., 2015). However, towards the southeastern end of the Canal we traced an ENE-WSW trending fault (the Kalamaki-Isthmia fault), dipping $60^{\circ}-65^{\circ}$ towards the SSE (e.g. Collier, 1990; Pallikarakis et al., 2015; Papanikolaou et al., 2015). It offsets Middle and Upper Pleistocene sediments and bounds alluvial deposits that are located on its hangingwall. Its length is approximately $5.5 \mathrm{~km}$, but it controls the topography of the area, producing up to $150 \mathrm{~m}$ of displacement towards its centre. Towards its central part the upper layers dip $5^{\circ}$ to $10^{\circ}$ towards NNW, while the lower layers dip $20^{\circ}$ to $35^{\circ}$ towards NNW. Layers in the centre of the fault dip $35^{\circ}$ while these closer to its tip dip $5^{\circ}$ to $15^{\circ}$ to the NNW (Papanikolaou et al., 2015).

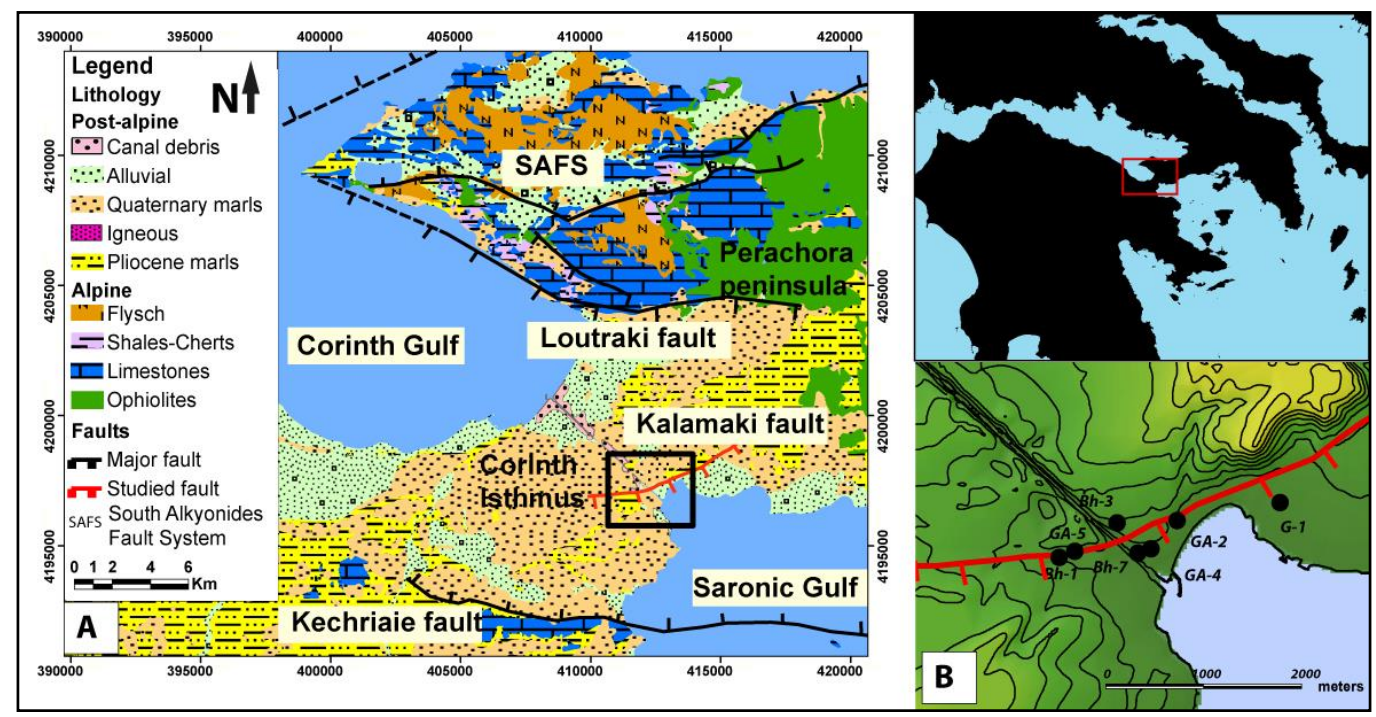

Figure 1 - A) Simplified geological map showing the major faults; the Kalamaki-Isthmia fault is highlighted in red (modified from Bornovas et al., 1972, 1984; Collier, 1990; Gaitanakis et al., 1985; Papanikolaou et al., 1989, 1996, 2015). B) Boreholes location at the footwall and hanging-wall of the Kalamaki fault.

\section{Materials and Methods}

Samples from nine boreholes which were drilled on either side of the Kalamaki-Isthmia fault were examined for micropaleontological content. $292 \mathrm{~m}$ of cores were examined and 252 samples were 
extracted (Figure 2). We described alternations of sand, clay, clayey sand, conglomerate, marl, fractions of limestone and topsoil within the borehole cores. We encountered the same complicated lithological pattern within the boreholes and through geological mapping. There is a poor correlation among these layers. The latter indicates that there are major lateral alternations and stratigraphic variations. A series of different depositional environments were recognized through micropaleontological analysis of the benthic foraminiferal fauna (Figure 3) (e.g. Triantaphyllou et al., 2003).
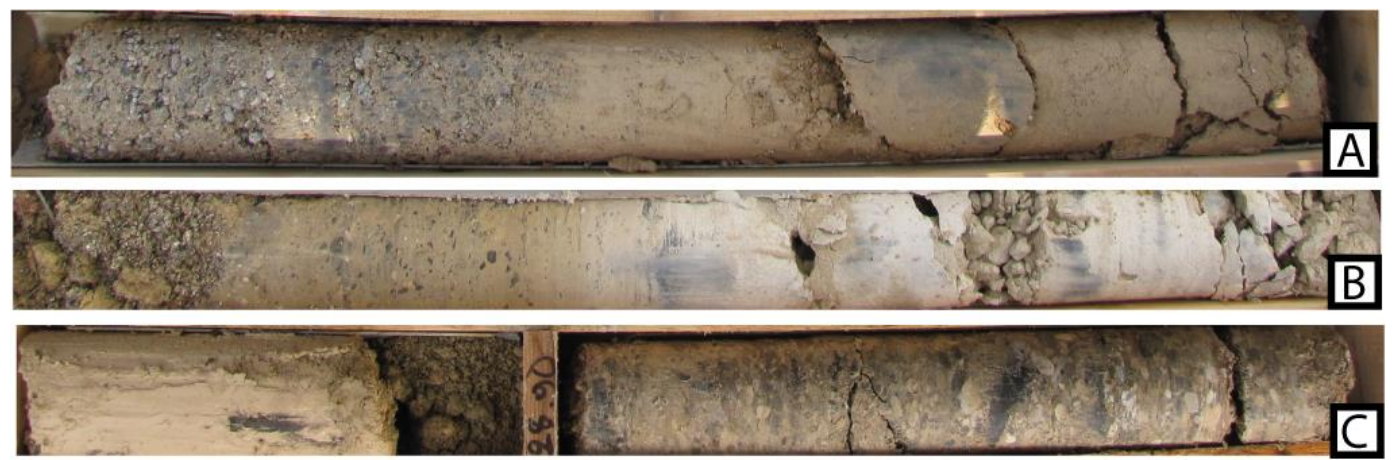

Figure 2 - Samples from the drill cores. (A) Borehole GA-4 from $18.30 \mathrm{~m}-\mathbf{1 9 . 2 0}$ m, showing the transition from fluvial (gravels) to marine (silt). (B) Borehole GA-4 from 33.00 m - 33.90 $\mathrm{m}$, showing the transition from gravels to sitly sand. (C) Borehole GA-5 from $28.60 \mathrm{~m}-29.70$ $\mathrm{m}$, showing the transition from marine (clayey sand) to fluvial gravels.

We have described and analysed borehole cores focusing on the micropaleontological content. Alternations of clay, sand, and gravels were encountered and the paleoenvironmental conditions varied from fluvial-terrestrial to marine. The paleoenvironment was grouped into six categories:

- Fluvial-terrestrial (F) deposits representing torrential events consisting mostly of wellrounded gravels and to a lesser degree sand.

- Coastal (Co) rounded sands and fine gravels representing foreshore paleoenvironment.

- Shallow (less than $30 \mathrm{~m}$ depth) marine (M) shoreface deposits of fine sands and clays.

- Shallow marine (SM) gravels and sands with mesohaline features influenced by freshwater input. This suggests that the paleoenvironment was probably nearest to the coast and shallower than (M).

- Lagoonal clays (L), fine sands and rare gravels indicating a very shallow and closed marine paleoenvironment.

- Brackish-Oligohaline $(\mathrm{Br})$, which consists of clay and fine sand and is similar to a lacustrine environment.

The magnetic susceptibility (MS) of sediments depends mostly on mineral composition and grain size. In general, iron bearing minerals lead to high values of MS (dimensionless SI units) (e.g., Mullins, 1997; Oldfield, 1991; Da Silva et al., 2009; Reicherter et al., 2010). Terrestrial deposits are often characterized by higher amounts of such minerals compared to marine sediments; therefore MS measurements can help to distinguish between different sedimentary environments. For our study we used the Bartington MS2 system with the MS2K sensor (see also Reicherter et al., 2010). The MS measurements were taken in the laboratory every $2 \mathrm{~cm}$ along each core or by calculating the average value if the sample was in a sample bag. In total, 992 MS measurements were carried out on nine different borehole cores. Based on the core descriptions, we correlated the lithology and the paleoenvironment with the MS measurements. 

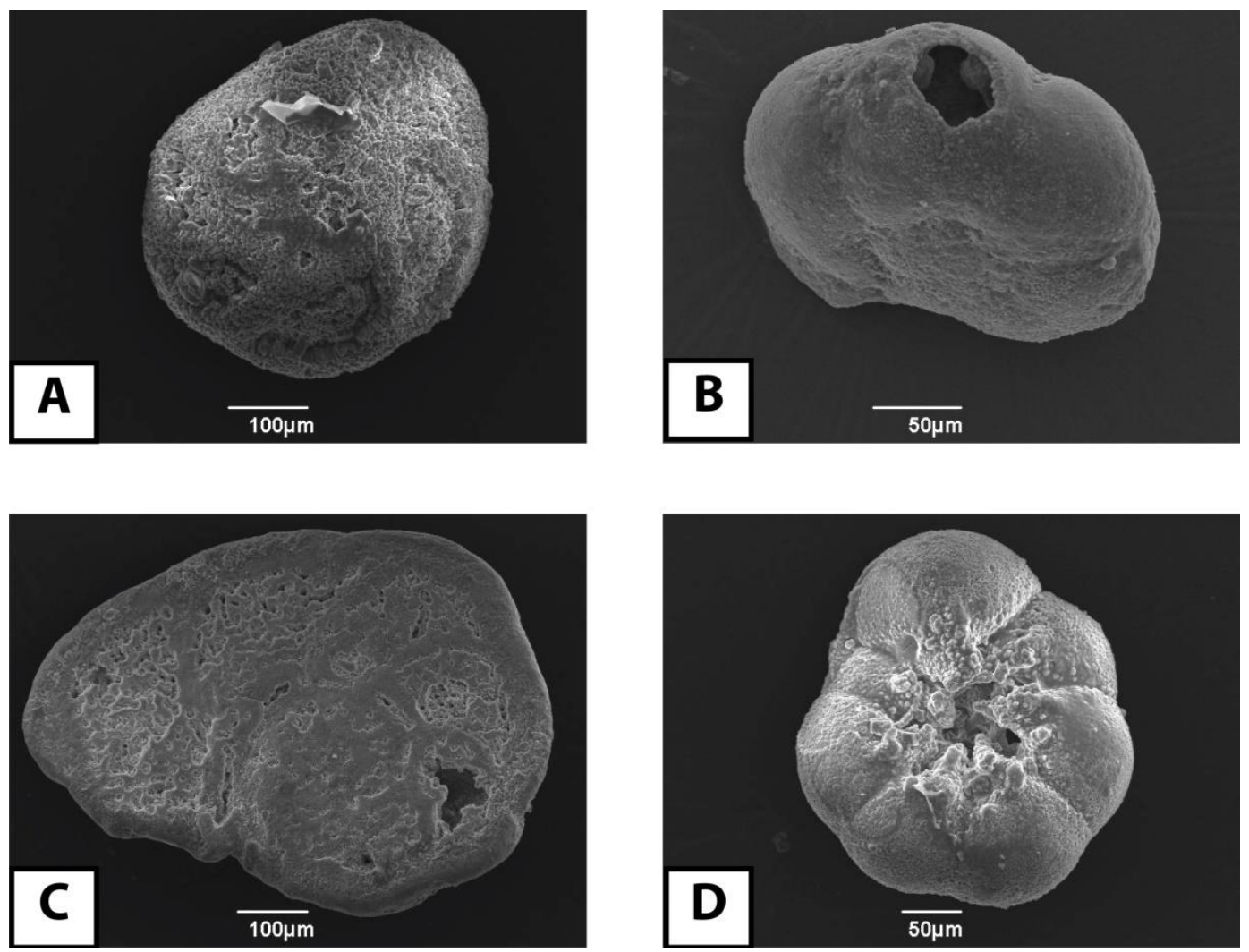

Figure 3 - (A) Rosalina sp., (B) Aubignyna sp. (broken), (C) Cibicides sp., (D) Ammonia sp. Foraminiferal species that were found within boreholes, indicating a shallow marine environment (A), (C) or a lagoonal environment (B), (D) Results.

Micropaleontological analysis showed a complicated paleoenvironmental pattern (Pallikarakis et al., 2015). In borehole Bh-1 we identified mainly alternations of lagoonal with shallow marine sediments, interrupted by a fluvial-terrestrial layer. Paleoenvironment in borehole Bh-3 and Bh-7 is more complicated. We identified several alternations of shallow marine to lagoonal sediments, interrupted by terrestrial or fluvial terrestrial sediments. At $22 \mathrm{~m}$ depth in Bh-3 and at $24 \mathrm{~m}$ depth in Bh-7 a lagoonal layer with abundant small size Ammonia has been found. In Bh-3 at $21 \mathrm{~m}$ depth and in Bh-7 at 18 m depth we found a Cladocora caespitosa corals colony in situ. In Bh-7 from 33 to 45 $\mathrm{m}$ depth we found fault's deformation zone with alternations of cataclastites and fragments of limestones. The entire borehole G-1 was described as terrestrial - fluvial paleoenvironment, while borehole G-2 was characterized mainly as lagoonal paleoenvironment interrupted by thin layers of shallow marine paleoenvironment. Borehole GA-2 was described as lagoonal to shallow marine with mesohaline features. In borehole GA-3 we identified a shallow marine with mesohaline features to coastal paleoenvironment. The end of the borehole is characterized as fluvial terrestrial paleoenvironment. In borehole GA-4 we mostly identified alternations of shallow marine and lagoonal sediments, interrupted by coastal and fluvial sediments. Borehole GA-5 is mainly characterized by alternations of coastal to shallow marine with mesohaline features and shallow marine paleoenvironments (Figure 4). 


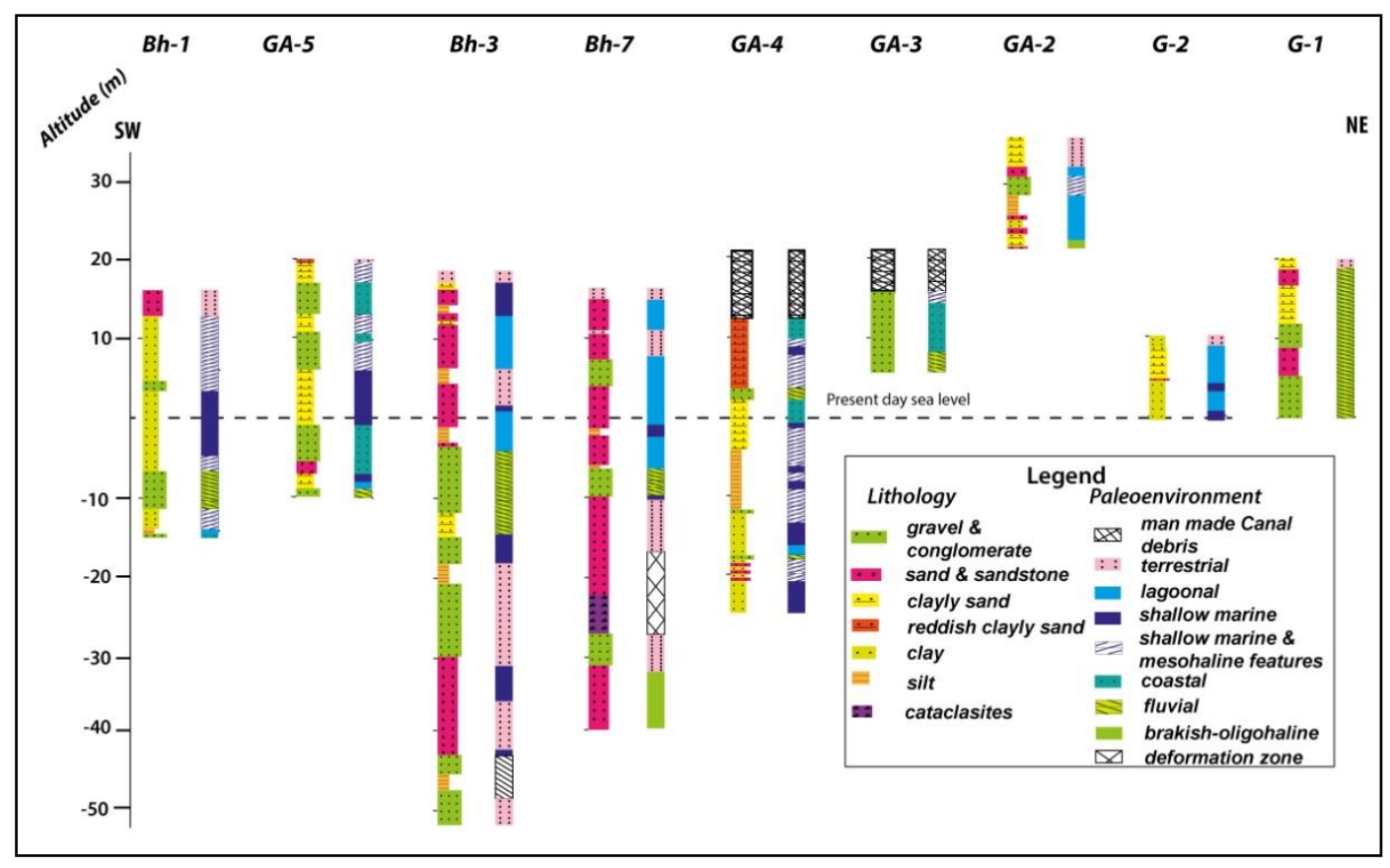

Figure 4 - Most of the boreholes were drilled at the immediate hangingwall of the fault. Even to neighbouring boreholes, there is a poor correlation showing the complexity of the sedimentological and paleoenvironmetal pattern.

MS measurements show a clear difference between marine and terrestrial sediments. Higher values are measured in gravely layers, while clayey and sandy layers have less magnetic susceptibility. Shallow marine layers with mesohaline features were influenced by fresh water. High diversity within these layers is due to the fact that gravels were transported by torrential rainfall events (Figures 5, 6). Shallow marine sediments have lower MS ranging from 1 to 70 SI. Lagoonal sediments have a unique imprint as well. Here, the MS signal ranges from 3 - 70 SI and is less than 30 SI in most cases. However, in Bh-7, lagoonal sediments contain clasts which affect the MS signal, and as a result higher MS values were measured. Coastal layers range from 4 - 253 SI, as they mostly consist of transported rounded clasts and grains. Gravely sediments have a distinct imprint with values ranging from 12 - 164 when the clasts consist of limestone or 75 - 582 when the clasts consist of Ophiolites. In Bh-1 core MS measurements range from 5 - 267 SI. The lower part of the core is characterized by higher MS values. In Bh-3 MS values range from 1 - 207 SI and follow the changes of the described environment. In Bh-7 MS values range from 1 to 227 SI. In GA-2 core MS measurements in the upper part range from 1 to 97 SI, while the brackish layer has values of 7 to 9 SI. In GA-3 core MS measurements at the lower fluvial part range from 184.5 to 262 ; then from 75.5 to 253.5 for the coastal part; while the upper shallow marine part ranges from 97 to 312 . In borehole GA-4 MS measurements in lagoonal sediments range from 3 to 70 SI, in coastal sediments from 50 to 162 SI, in shallow marine sediments from 1 to 62 SI, in fluvial from 126 to 442 SI and in shallow marine with mesohaline features from 2 to 343 SI. In GA-5 MS values in the lagoonal environment range from 8 to $12 \mathrm{SI}$, in shallow marine from 3 to $20 \mathrm{SI}$, in coastal from 19 to 322.5 and in shallow marine with mesohaline features from 21 to 424 SI. 


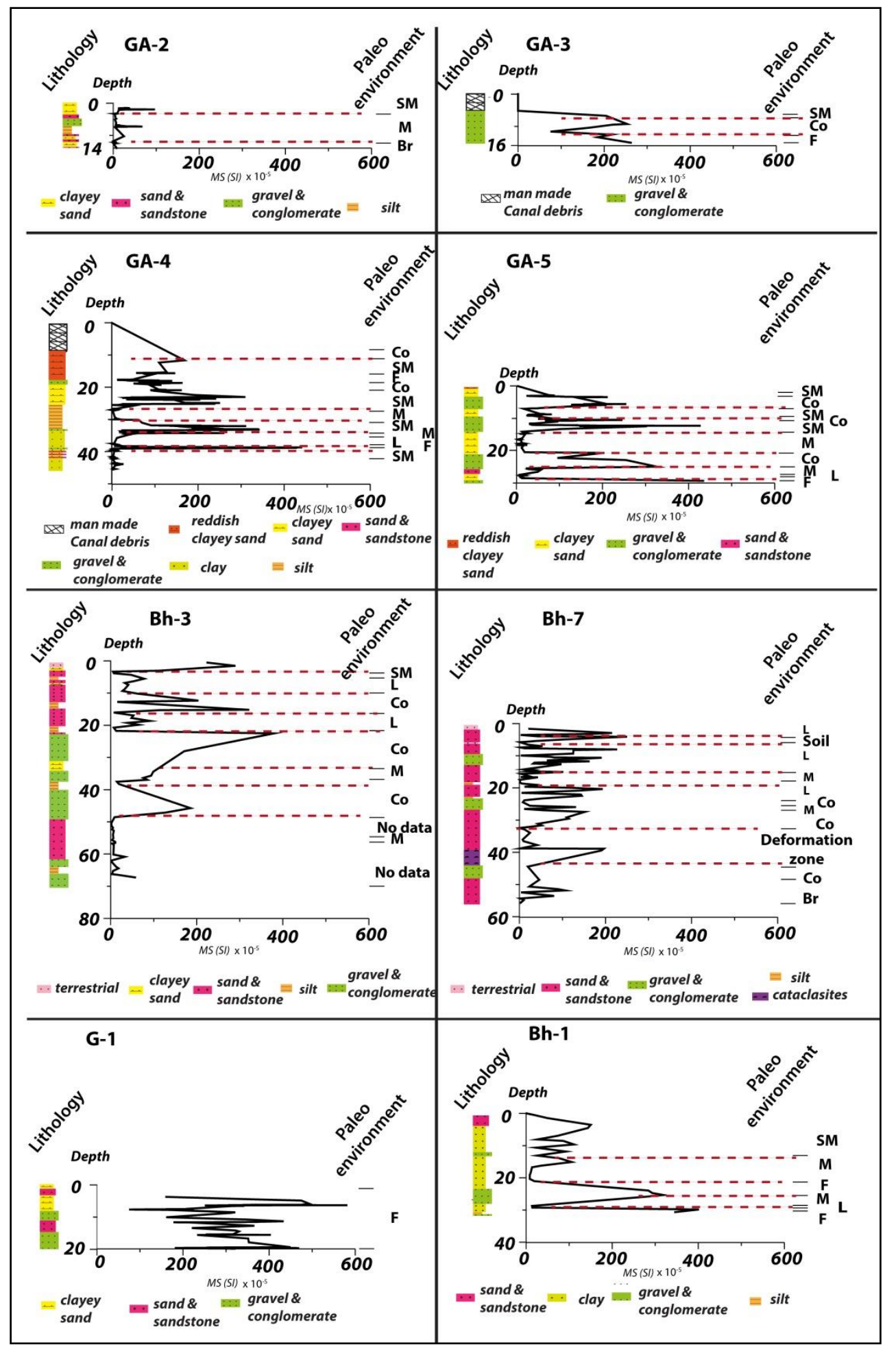

Figure 5- The magnetic susceptibility (MS) of sediments depends mostly on mineral composition and grain size (e.g., Mullins, 1997; Oldfield, 1991). The scale of $X$ and $Y$ axis is the same in all boreholes for assisting the comparison. See text for description. 


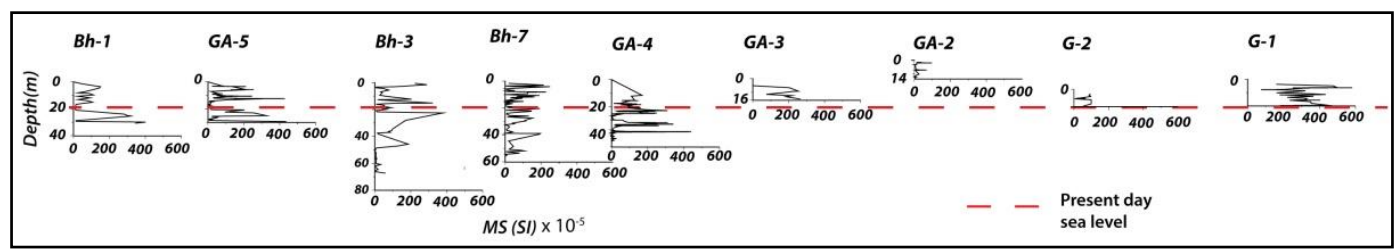

Figure 6 - All studied boreholes, in respect to the present sea level.

\section{Discussion}

We conclude that the boreholes show alternations of highstand and lowstand deposits when correlating marine sediments with glacioeustatic sea level highstands and terrestrial sediments with glacioeustatic lowstands. By correlating the known uplift rate of the area $(0.3 \mathrm{~mm} / \mathrm{yr}$ according to Collier et al., 1992), with global sea level change from Siddall et al. (2003), we can imply the relative dates of the sediments (Figure 7). We expect that the average age of the marine sediments within the boreholes is probably 125 to $200 \mathrm{ka}$, while within the deepest boreholes (Bh-3 and Bh-7) the age of marine layers are probably even 240 to $300 \mathrm{ka}$.

The Kalamaki-Isthmia fault is an active syn-sedimentary structure that offsets Pleistocene sediments and controls the morphology of the eastern part of the Canal with an elevation of up to $150 \mathrm{~m}$. The fault was highly active during sedimentation, since the upper layers towards fault's centre dip at higher angle than these to the lower part. The layers of the central part dip at a higher angle than those towards its tip, which indicates that the backtilting is controlled by the slip-rate variability from the center to the fault tip (Papanikolaou et al., 2015). The complicated paleoenvironmetal pattern is the result of the interplay between the glacioeustatic sea level changes and the tectonic movements.

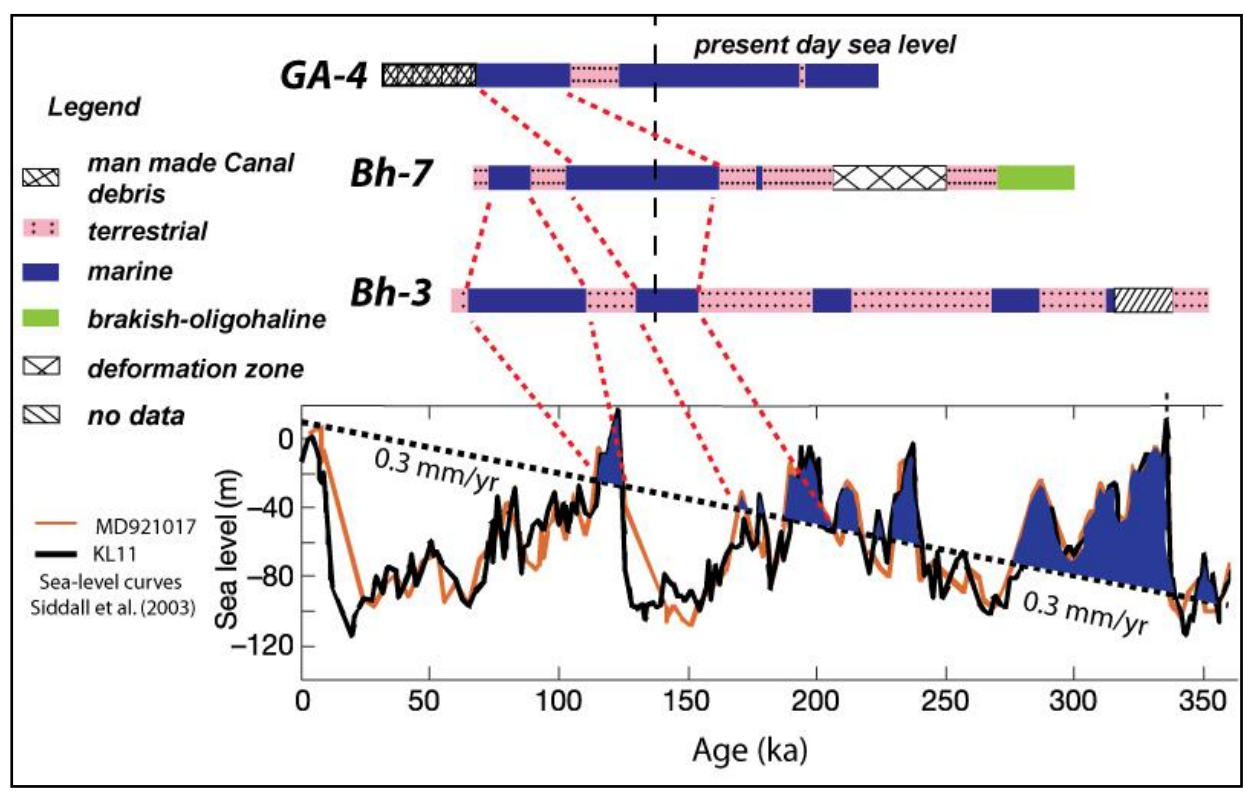

Figure 7- Simplified paleoenvironment in boreholes Bh-3, Bh-7 and GA-4, sea level curve from Siddall et al. (2003) and the expected depositional paleoenvironment based on the $0.3 \mathrm{~mm} / \mathrm{yr}$ uplift rate from the neighbouring dated corals of Collier et al. (1992). Expected marine paleoenvironments are highlighted with blue. 
MS measurements exhibit a clear difference between marine and terrestrial sediments. Ophiolite clasts within the fluvial terrestrial deposits lead to higher MS measurements. These clasts most likely originate from the Gerania Ophiolite nappes and could indicate higher erosional rates and transfer capacity. Therefore we suggest that these fluvial terrestrial sediments should have been transferred and deposited during the glacioeustatic lowstand, when the area was emerged. During emergence we observe higher erosion rates and thus high mobility and re-sedimentation of lowstand clasts of predominately ophiolitic origin. There is a relationship between ophiolite gravely layers with high MS and with glacioeustatic lowstand fluvial deposits (Gawthorpe et al., 1994). The presence of the fluvial Ophiolite clasts layer, which is traceable in most of the boreholes, is partially affected by the fault's activity.

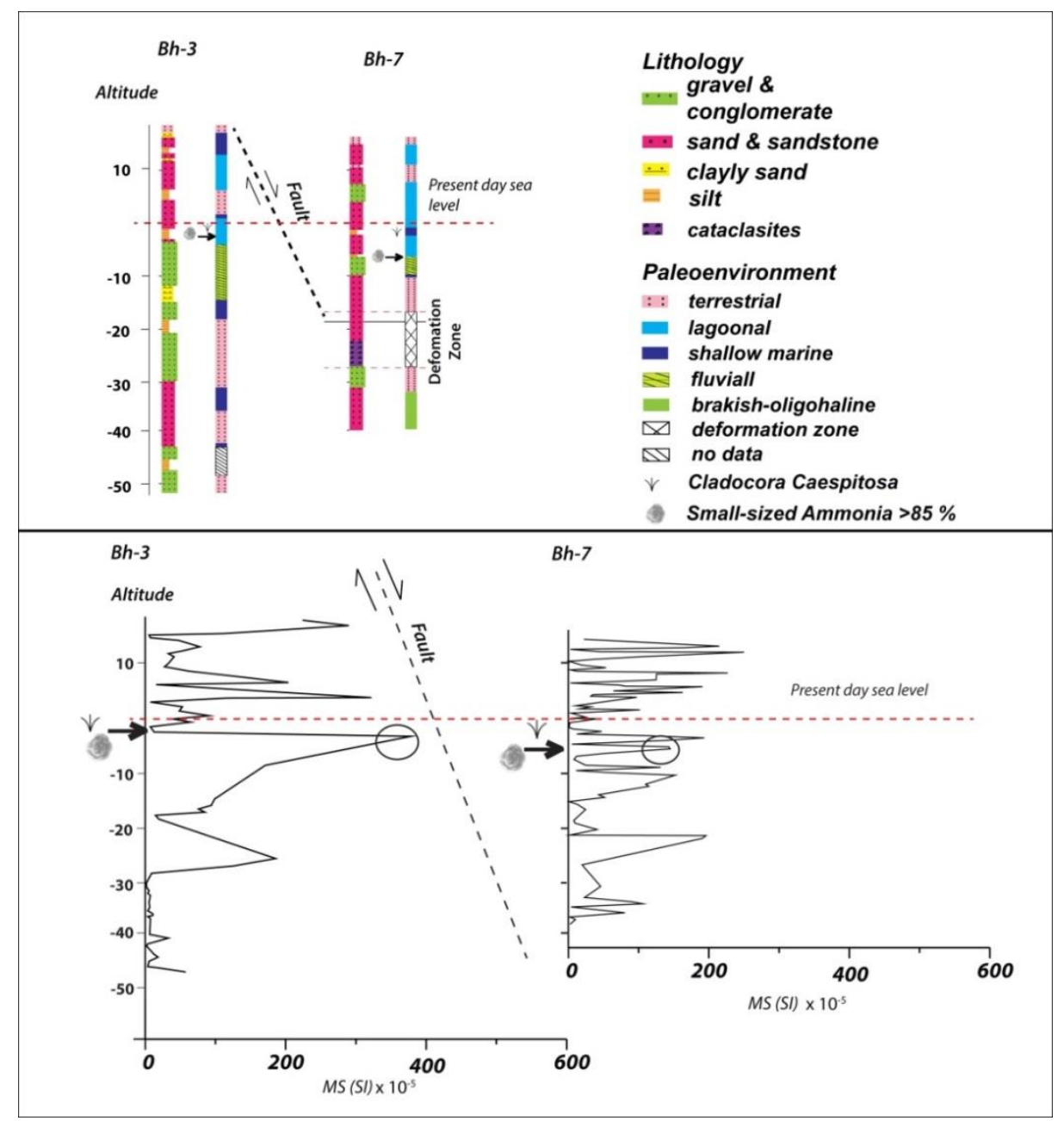

Figure 8 - Boreholes Bh-3 and Bh-7 were examined to estimate the faults slip rate by correlating Cladocora corals, a lagoonal horizon and magnetic susceptibility.

Papanikolaou et al. (2015) correlated lagoonal horizons from boreholes Bh-3 and Bh-7 to estimate the fault's mean slip rate at this site. The authors implied a $0.04 \pm 0.02 \mathrm{~mm} / \mathrm{yr}$ mean slip rate for the last $200 \mathrm{ka}$. Through magnetic susceptibility values we confirmed the connection between these two layers. Even though Bh-7 has poor correlation, the transition from marine to terrestrial is evident. By correlating the transition from low MS values to high MS values in boreholes Bh-3 and Bh-7, we conclude that the fault's mean slip rate for the same period is higher, around $0.05 \pm 0.02 \mathrm{~mm} / \mathrm{yr}$. The estimate of Papanikolaou et al. (2015) is based on foraminiferal assemblages, while in this paper 
we use MS values. Both methodologies are independent of each other. Either way, the KalamakiIsthmia fault is an active but low slip rate fault. MS measurements refine the interpretation of the drill cores, thus leading to a better understanding of the tectonic movements relative to sea level. Questions arise concerning the influence of the fault on the sedimentation pattern: To what extent does the fault control the sedimentation processes? Further analysis might help us distinguish between natural fluctuations in sedimentation rates and tectonically driven variability. However, we already understand that the complicated paleoenvironmental pattern is the result of the interplay between the glacioeustatic sea level changes and the tectonic movements.

\section{Conclusions}

- Magnetic Susceptibility has greater values in fluvial and terrestrial sediments than in shallow marine or lagoonal sediments. The presence of Ophiolites clasts mainly in fluvial sediments has helped us to distinguish a unique imprint of higher values, in comparison with the marine deposits.

- Paleoenvironmental examination has shown alternations of marine to terrestrial sediments within the boreholes. Correlating the glacioeustatic sea level changes with the tectonic uplift we suggest that the age of the sediments is from $125 \mathrm{ka}$ to $240 \mathrm{ka}$ and even $300 \mathrm{ka}$.

- The offset between lagoonal horizons in boreholes Bh-3 and Bh-7, mentioned by Papanikolaou et al. (2015) which they estimated the slip rate of the fault, is highlighted here as well by correlating the MS values in boreholes Bh-3 and Bh-7.

\section{Acknowledgments}

The Academy of Athens scholarship (Mitsopoulos Fund) is thanked for financial support.

\section{References}

Armijo, R., Meyer, B., King, G.C.P., Rigo. A. and Papanastassiou, D., 1996. Quaternary evolution of the Corinth Rift and its implications for the Late Cenozoic evolution of the Aegean, Geophys. J. Int., 126, 11-53.

Bornovas, J., Lalechos, N. and Filipakis, N., 1972. 1:50.000-scale geological map, Sheet -Korinthos. Institute of Geology and Mineral Exploration.

Bornovas, J., Gaitanakis, P. and Spiridopoulos, A., 1984. 1:50.000-scale geological map, Sheet Perachora, Institute of Geology and Mineral Exploration, Athens.

Collier, R.E.L., 1990. Eustatic and tectonic controls upon Quaternary coastal sedimentation in the Corinth Basin, Greece, J. Geol. Soc. London, 147, 301-314.

Collier, R.E.L. and Dart, C.J., 1991. Neogene to Quaternary rifting, sedimentation and uplift in the Corinth Basin, Greece, Journal of the Geological Society, London, 148, 1049-563 1065, doi: 10.1144/gsjgs.148.6.1049.

Collier, R.E.L. and Thompson, J., 1991. Transverse and linear dunes in an upper Pleistocene marine sequence, Corinth Basin, Greece, Sedimentology, 38, 1021-1040.

Collier, R.E.L., Leeder, R.M., Rowe, P. and Atkinson, T., 1992. Rates of tectonic uplift in the Corinth and Megara basins, Central Greece, Tectonics, 1159-1167.

Da Silva, A.C., Potma, K., Weissenberger, J.A.W., Whalen, M.T., Humblet, M., Mabille, C. and Boulvain, F., 2009: Magnetic susceptibility evolution and sedimentary environments on carbonate platform sediments and atolls, comparison of the Frasnian from Belgium and Alberta, Canada, Sed. Geol., 214, 3-18.

Freyberg, V., 1973. Geologie des Isthmus von Korinth, Erlanger Geologische Abhandlungen, Heft 95, Junge und Sohn, Universitätsbuchdruckerei Erlangen, 183 pp. (in German). 
Gawthorpe, R.L., Fraser, A.Jj. and Collier, R., 1994. Sequence stratigraphy in active extensional basins: implications for the interpretation of ancient basin fills, Marine and Petroleum Geology, 11, 642-658.

Gaitanakis, P., Mettos, A. and Fytikas, M., 1984. 1:50.000 scale geological map, Sheet "Sofikon", Institute of Geology and Mineral Exploration.

Mullins, C.E., 1977. Magnetic susceptibility of the soil and its significance in soil science-a review, Journal of soil science, 28(2), 223-246.

Oldfield, F., 1991. Environmental magnetism-a personal perspective, Quaternary Science Reviews, 10(1), 73-85.

Pallikarakis, A., Papanikolaou, I., Triantaphyllou, M., Reicherter, K. and Migiros, G., 2015. Study of an active fault at the eastern tip of the Corinth Canal, through surface and borehole data, Proceedings of the 6th International INQUA Meeting on Paleoseismology, Active Tectonics and Archaeoseismology, 19-24 April 2015, Pescina, Fucino Basin, Italy, 04/2015, 336-341.

Papanikolaou, D., Chronis, G., Lykousis, V., Pavlakis, P., Roussakis, G. and Syskakis, D., 1989. 1:100.000 scale, Offshore Neotectonic Map the Saronic Gulf. Earthquake Planning and Protection Organization, National Centre for Marine Research, University of Athens.

Papanikolaou, D., Logos, E., Lozios, S. and Sideris, Ch., 1996. 1:100.000 scale Neotectonic Map of Korinthos Sheet, Earthquake Planning and Protection Organization, Athens.

Papanikolaou, I.D., Triantaphyllou, M., Pallikarakis, A. and Migiros, G., 2015. Active faulting at the Corinth Canal based on surface observations, borehole data and paleoenvironmental interpretations, Passive rupture during the 1981 earthquake sequence? Geomorphology, 237, 65-78.

Reicherter, K., Vonberg, D., Koster B., Fernández-Steeger, T., Grützner, C. and Mathes-Schmidt, M., 2010. The sedimentary inventory of tsunamis along the southern Gulf of Cádiz (southwestern Spain), Zeitschrift für Geomorphologie, 54(3), 147-173.

Roberts, G.P., Houghton, S.L., Underwood, C., Papanikolaou, I., Cowie, P.A., van Calsteren, P., Wigley, T., Cooper, F.J. and McArthur, J.M., 2009. Localization of Quaternary slip rates in an active rift in $10^{5}$ years: An example from central Greece constrained by 234U-230Th coral dates from uplifted paleoshorelines, Journal of Geophysical Research, 114, B10406, doi: 10.1029/2008JB0058.

Siddall, M., Rohling, E.J., Almogi-Labin, A., Hemleben, Ch., Meischner, D., Schmelzer, I. and Smeed, D.A., 2003. Sea-level fluctuations during the last glacial cycle, Nature, 423, 853858.

Triantaphyllou, M.V., Pavlopoulos, K., Tsourou, Th. and Dermitzakis, M.D., 2003. Brackish marsh benthic microfauna and paleoenvironmental changes during the last 6.000 years on the coastal plain of Marathon (SE Greece), Rivista Italiana Paleontologia et Stratigafia, 109(3), 539-547. 